\title{
Purification and characterization of the free form of the lactococcal extracellular proteinase and its autoproteolytic cleavage products
}

\author{
JoN NisSEN-MeYeR ${ }^{1 *}$ and KNUt SLetTEN ${ }^{2}$ \\ ${ }^{1}$ Laboratory of Microbial Gene Technology, Post Box 51, N-1432 As-NLH, Norway \\ ${ }^{2}$ Department of Biochemistry, University of Oslo, Norway
}

(Received 17 October 1990; revised 1 March 1991; accepted 5 March 1991)

\begin{abstract}
In addition to the cell wall proteinase, Lactococcus lactis subsp. cremoris produced significant amounts of a free extracellular proteinase. The free proteinase activity was highest in the late exponential and early stationary phase of growth, whereas the cell wall activity was highest in the last half of the exponential phase. Both proteinase forms had a pH optimum between 4.6 and 5.8, and they behaved similarly upon anion exchange and hydrophobic interaction chromatography, chromatofocusing and gel filtration, indicating that they were related. Purification to homogeneity, as judged by SDS-PAGE, resulted in a 50000-80000-fold increase in the specific activity of the free proteinase. It contained two major protein species (termed pro150 and pro115) with proteinase activity. As judged by SDS-PAGE, the $M_{\mathrm{r}}$ values of pro150 and pro115 were 150000 and 115000 , respectively, and by chromatofocusing the isoelectric points were $4 \cdot 3$ and 4.1, respectively. Upon gel filtration, pro150 and pro115 had $M_{\mathrm{r}}$ values of 300000 and 125000 , respectively, indicating that pro150 was a dimer and pro1 15 a monomer. Pro115 was an autodegradation product of pro150. Other distinct autodegradation products had $M_{\mathrm{r}}$ values of 90000 (p90), 53000 (p53), 37000 (p37) and 30000 (p30). These had little if any proteinase activity. Pro115, p90 and p53 had a common $\mathbf{N}$-terminal sequence with that reported for the cell wall proteinase. Judging from its $\mathbf{N}$-terminal sequence and $M_{r}$, p30 was derived from the C-terminal half of p53. Cleavage of pro150 to pro115 generated p37.
\end{abstract}

\section{Introduction}

The proteolytic enzymes of lactococci are of importance in the use of these bacteria in the production of fermented milk products. Degradation of milk proteins is essential for growth of these bacteria on milk products as well as for the development of the products' texture and flavour (Fox, 1989; Law \& Kolstad, 1983; Thomas \& Mills, 1981). Thus, knowledge as to the types of proteinases that appear extracellularly during growth of lactococci - the substrate specificity and biochemical characteristics of the proteinases, and how the enzymes vary in different strains - is of importance in the use of lactococci in food production. Consequently, a proteinase(s) associated with the cell wall has been the subject of much research and the genetics of this proteinase have recently been well characterized (Haandrikman et al., 1989; Kok et al., 1988a, b; Kok \& Venema, 1988; Vos et $a l ., 1989 a, b$ ).

In the present study we found that many strains of lactococci released significant amounts of proteinase activity into the growth medium. We report here the purification to homogeneity of the free extracellular proteinase of one strain. The enzyme was characterized and directly compared to the cell wall proteinase to determine whether the free proteinase was novel or was related to the cell wall proteinase. In addition, characteristic autoproteolytic degradation products as well as areas of the proteinase which are prone to autoproteolytic cleavage have been identified.

\section{Methods}

Bacterial strains and media. Lactococcus lactis subsp. cremoris NCDO 1201, obtained from the National Collection of Food Bacteria, AFRC Institute of Food Research, Reading, UK, was grown at $30^{\circ} \mathrm{C}$ in $\mathrm{M} 17$ broth (Oxoid) without lactose, but supplemented with $0.5 \%(\mathrm{w} / \mathrm{v})$ glucose.

Assay for proteinase activity. Proteinase activity was assayed by measuring production of trichloroacetic acid (TCA)-soluble radioactive peptides from an $\left[{ }^{3} \mathrm{H}\right]$ acetylcasein substrate, essentially as described by Hatcher $e t$ al. (1977). The assay was carried out in $200 \mu \mathrm{l}$ reaction mixtures containing $200 \mathrm{~mm}$-sodium phosphate ( $\mathrm{pH} \mathrm{5.3)}$, radioactive casein $\left(5 \times 10^{4}\right.$ c.p.m.; sp act: 50 c.p.m. $\left.\mathrm{ng}^{-1}\right)$ and various amounts of proteinase-containing fractions. The reaction mixtures were incubated for $2 \mathrm{~h}$ at $37^{\circ} \mathrm{C}$. One hundred microlitres of a $2.5 \%$ $(\mathrm{w} / \mathrm{v})$ solution of unlabelled casein in $20 \mathrm{~mm}$-sodium phosphate $(\mathrm{pH} 7 \cdot 1)$ and $1 \mathrm{M}-\mathrm{KCl}$ were then added to each reaction mixture, followed by 
$200 \mu \mathrm{l}$ ice-cold $7.5 \%$ (w/v) TCA. The reaction mixtures were then centrifuged at $14000 \mathrm{~g}$ for $10 \mathrm{~min}$, and the radioactivity in the supernatants was measured in a liquid scintillation counter. One enzyme unit (EU) was defined as the amount of enzyme that degrades $1 \%$ of the ${ }^{3} \mathrm{H}$-labelled casein into TCA-soluble products under standard assay conditions.

Ammonium sulphate precipitation and binding to Phenyl Sepharose. For purification of the free extracellular proteinase, an overnight culture in the early stationary phase was rendered cell-free by centrifugation at $4000 \mathrm{~g}$ for $15 \mathrm{~min}$. Three hundred grams $\left(\mathrm{NH}_{4}\right)_{2} \mathrm{SO}_{4}$ per litre of cellfree culture medium $\left(10-4{ }^{\circ} \mathrm{C}\right)$ were then added. The precipitated proteins were pelleted by centrifugation at $7000 \mathrm{~g}$ for $20 \mathrm{~min}$ and solubilized in $20 \mathrm{~mm}$-Bistris, pH 5.8 ( $50 \mathrm{ml}$ per litre culture medium); this resulted in a $200-300-$ fold increase in the specific activity of the proteinase and a 20 -fold concentration (see Table 1). Four grams of $\left(\mathrm{NH}_{4}\right)_{2} \mathrm{SO}_{4}$ were then added per $50 \mathrm{ml}$ of the solubilized protein preparation, and it was applied to a $10 \mathrm{ml}$ Phenyl Sepharose CL-4B (Pharmacia) column which had been equilibrated with $20 \mathrm{~mm}$-Bistris, pH 5.8, and $0.6 \mathrm{M}-\left(\mathrm{NH}_{4}\right)_{2} \mathrm{SO}_{4}$. The proteinase was eluted with $15-$ $20 \mathrm{ml} 20 \mathrm{~mm}$-Bistris, $\mathrm{pH} 5.8$. This resulted in a 1000-5000-fold increase in the specificactivity of the proteinase and a yield of $200-300 \%$ (see Table 1).

For purification of the cell wall-associated proteinase, bacteria were harvested in the late exponential phase of growth by centrifugation at $4000 \mathrm{~g}$ for $15 \mathrm{~min}$. The bacteria were washed once in $20 \mathrm{~mm}-\mathrm{Tris} / \mathrm{HCl}$, $\mathrm{pH} 7 \cdot 2$, and $15 \mathrm{~mm}-\mathrm{CaCl}_{2}$ (200 ml per litre of culture), and then suspended with stirring for $4 \mathrm{~h}$ at $20^{\circ} \mathrm{C}$ in $20 \mathrm{mM}-\mathrm{Tris} / \mathrm{HCl}, \mathrm{pH} 7 \cdot 2$, and $15 \mathrm{~mm}$-EDTA ( $40 \mathrm{ml}$ per litre of culture). The $\mathrm{CaCl}_{2}$ was included in the former buffer in order to minimize release of the cell wall proteinase when washing the cells, whereas the presence of EDTA in the latter buffer was to optimize its release (Laan \& Konings, 1989). The $\mathrm{Ca}^{2+}$. containing washing buffer did not have significant proteolytic activity, and thus the free proteinase did not contribute to the activity in the cellwall-derived proteinase preparation. The bacteria were then removed by centrifugation, and $\left(\mathrm{NH}_{4}\right)_{2} \mathrm{SO}_{4}$ was added to a final concentration of $1 \mathrm{M}$ to the supernatant, which contained the cell-wall-derived proteinase, after which the supernatant was applied to a $5 \mathrm{ml}$ Phenyl Sepharose CL-4B column. The cell-wall-derived proteinase was eluted from the column with $10 \mathrm{ml} 20 \mathrm{mM}-\mathrm{Tris} / \mathrm{HCl}, \mathrm{pH} 7 \cdot 2$. This resulted in a nearly 10 -fold purification and a recovery of $80-90 \%$ compared to that obtained after release of the proteinase (see Table 1). When starting with equal volumes of cell cultures, about five times more of the free than the cell wall proteinase was obtained at this stage (Table 1).

Ion exchange and hydrophobic interaction chromatography. The proteinase which eluted from the Phenyl Sepharose column was transferred to $20 \mathrm{~mm}$-Bistris, pH 5.8, by gel filtration using Sephadex G-25 PD-10 columns (Pharmacia), and subsequently applied to a Mono Q HR 5/5 anion exchange column (Pharmacia) equilibrated with $20 \mathrm{~mm}$-Bistris, $\mathrm{pH} 5.8$. The proteins were eluted with a gradient of $\mathrm{NaCl}$ in the Bistris buffer. Ammonium sulphate to a final concentration of $1 \mathrm{M}$ was added to the proteinase-containing fractions, which were then applied to a Phenyl Superose HR 5/5 column (Pharmacia) equilibrated with $20 \mathrm{~mm}$-Bistris, $\mathrm{pH} 5 \cdot 8$, and $1 \mathrm{M}-\left(\mathrm{NH}_{4}\right)_{2} \mathrm{SO}_{4}$. The proteins were eluted from the column by decreasing the concentration of $\left(\mathrm{NH}_{4}\right)_{2} \mathrm{SO}_{4}$.

Chromatofocusing and gel filtration. The proteinase obtained after hydrophobic interaction chromatography was transferred to $25 \mathrm{mM}$ methylpiperazine, $\mathrm{pH} 5 \cdot 7$, by gel filtration using the PD-10 columns as described above, and then applied to a Mono P HR 5/20 column (Pharmacia) equilibrated with the methylpiperazine buffer. The proteins were eluted from the column with polybuffer $74, \mathrm{pH} 3.5$ (Pharmacia). The proteinase was then applied to a Sephacryl S-200 (Pharmacia) column $(90 \times 2.6 \mathrm{~cm})$ and eluted with $0.1 \mathrm{M}-\mathrm{NaCl}$ in
20 mM-sodium phosphate, $\mathrm{pH} 7 \cdot 0$. The column was calibrated with blue dextran, ferritin $\left(M_{\mathrm{r}} 440000\right)$, catalase $(232000)$, aldolase (158000), bovine serum albumin (67000), ovalbumin (43000), chymotrypsinogen (25000) and RNAase A (13700). All chromatography was performed at $20^{\circ} \mathrm{C}$, with flow rates of $1 \mathrm{ml} \mathrm{min}^{-1}$ and with the use of the FPLC system (Pharmacia).

SDS polyacrylamide gel electrophoresis (SDS-PAGE). Protein fractions were analysed by SDS-PAGE using the Phast-System (Pharmacia), and the 8-25\% gradient polyacrylamide gels were stained using the PhastGel Silver Kit (Pharmacia). The high- $M_{\mathrm{r}}$ standards (Pharmacia) were myosin $\left(M_{\mathrm{r}} 212000\right), \alpha$-macroglobulin (170000), $\beta$-galactosidase (116000), transferrin $(76000)$ and glutamic dehydrogenase $(53000)$. The low- $M_{\mathrm{r}}$ standards (Bio-Rad) were phosphorylase $b\left(M_{\mathrm{r}}\right.$ 97400), bovine serum albumin (66200), ovalbumin (43000), carbonic anhydrase $(31000)$, soybean trypsin inhibitor $(21500)$ and lysozyme (14400).

Amino acid sequence analysis. Proteins to be sequenced were concentrated using Centricon Microconcentrators (Amicon). Nterminal amino acid sequence analysis was performed on these samples using an Applied Biosystems 477A protein sequencer. The phenylthiohydantoin-derivatized amino acid residues were determined on line by an Applied Biosystems 120 phenylthiohydantoin analyser. The proteins needed for $\mathrm{N}$-terminal sequencing were purified from $6-9$ litres of culture.

\section{Results and Discussion}

\section{Proteinase activity in various growth phases, and $\mathrm{pH}$ optimum}

In addition to the well-characterized cell-wall-associated proteinase, Lactococcus lactis subsp. cremoris produced a free extracellular proteinase(s). Out of 28 arbitrarily chosen strains tested in the early stationary phase of growth, 22 released significant amounts of proteinase activity into the growth medium, the amount of activity released often being comparable to the amount associated with the cell wall (data not shown). This prompted us to purify the free proteinase and directly compare it to the cell wall-associated proteinase. The strain NCDO 1201 produced the largest amount of free extracellular activity, and the proteinase from this strain was consequently chosen for further study.

The amount of proteolytic activity present during the various growth phases was determined, in order to obtain high yields for purification. The free activity was highest at the very end of the exponential phase and in the early stationary phase, whereas the cell-wall-associated activity was greatest during the last half of the exponential phase, and fell in the early stationary phase (Fig. 1). Thus, the kinetics of accumulation of the proteinases suggested that they might be related, as did the fact that the two enzymes had the same $\mathrm{pH}$ optimum - between pH 4.6 and 5.8 (data not shown). This $\mathrm{pH}$ optimum was similar to the value of 5.5-6.0 reported by Geis et al. (1985), but significantly less than the $6 \cdot 2-6.6$ reported by 


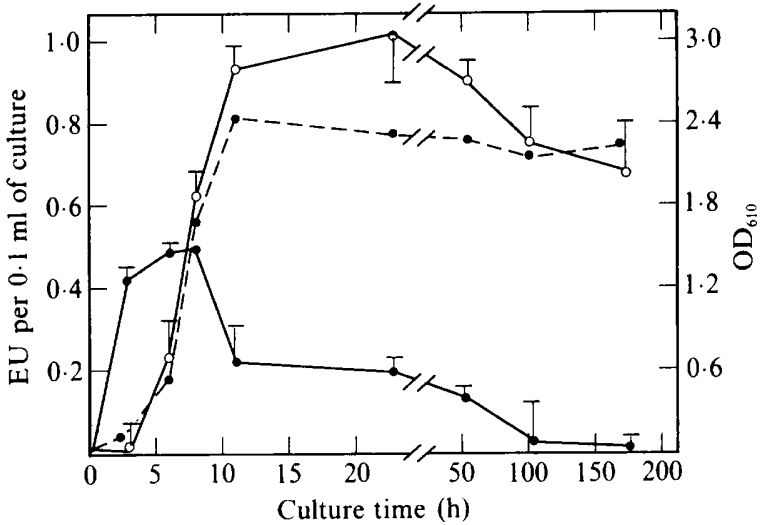

Fig. 1. Amount of free $(\mathrm{O}-\mathrm{O})$ and cell-wall-associated $(\mathbf{O}-\mathbf{O})$ proteinase activity during growth of a culture of $L$. lactis subsp. cremoris NCDO 1201. Samples were taken at the indicated times and the $\mathrm{OD}_{610}$ (-) was measured. The bacteria in the samples were pelleted and resuspended in an equal volume of $20 \mathrm{~mm}$-sodium phosphate, $\mathrm{pH} 5.5$, and the proteinase activity in the supernatant (free proteinase) and bacterial suspension (cell-wall-associated proteinase) was measured.

Exterkate \& de Veer (1987) for the cell wall proteinases from other strains.

\section{Anion exchange and hydrophobic interaction chromatography}

Upon chromatography of the partially purified proteinase fractions (see Methods) on a Mono Q anion exchange column, the free and cell wall proteinases eluted from the column at similar salt concentrations. However, the free proteinase had a broader elution profile and was thus more heterogeneous than the cell wall proteinase (Fig. 2). The cell wall proteinase was also somewhat heterogeneous, in that two partly overlapping activity peaks were obtained (Fig. $2 b$ ). The heterogeneity was in part due to the fact that the proteinase activity derived from two major proteins, one of which was a cleavage product of the other (results presented below). Moreover, immunological studies suggest that the cell wall proteinase may exist in two or more distinct conformations (Hugenholtz et al., 1984, 1987; Kok et al., 1988 a; Laan et al., 1988), and this conformational heterogeneity might also explain the heterogeneous chromatographic behaviour.

Upon further purification by hydrophobic interaction chromatography, the free proteinase eluted at a slightly higher salt concentration than the cell wall proteinase (Fig. 3), and thus was overall somewhat less hydrophobic. At this stage the specific activity had increased by $70000-80000$-fold, with a $200-300 \%$ yield, for the free proteinase, and by $500-600$-fold, with a $40-50 \%$ yield, for the cell wall proteinase (Table 1). For both proteinases a specific activity of about 40000 was

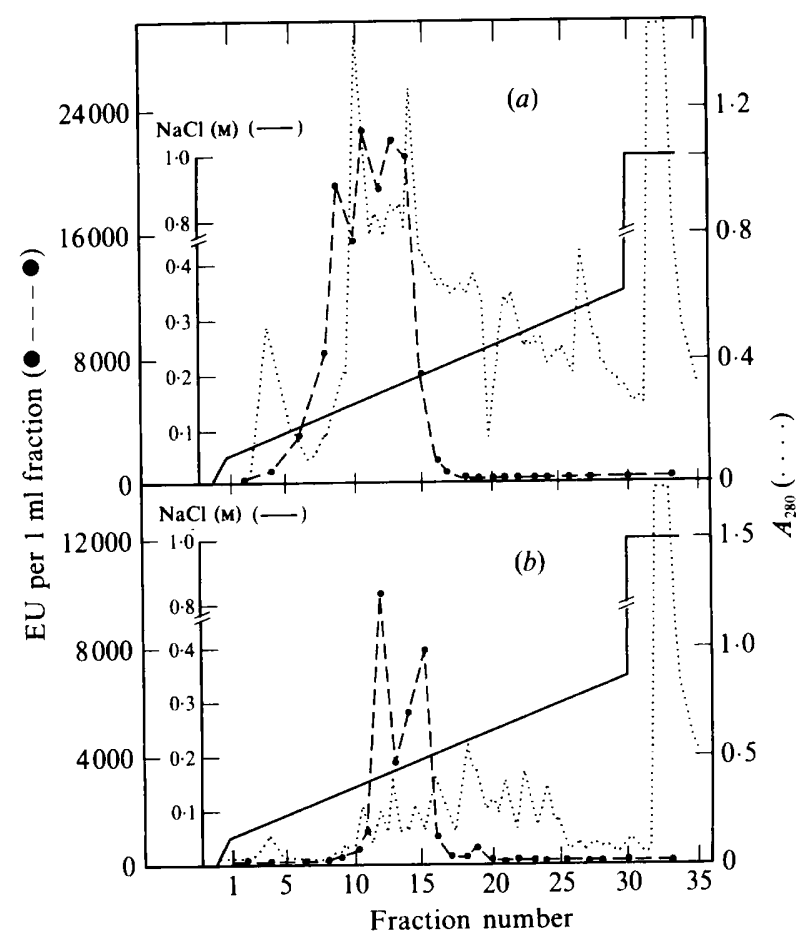

Fig. 2. Chromatography on a Mono $Q$ anion exchange column of the (a) free and $(b)$ cell wall proteinases which eluted from the Phenyl Sepharose column. The proteinases were from a 3 litre culture. No activity was detected in the flow-through fraction.

attained (Table 1), and this appears to be the specific activity of the pure enzymes. In some experiments, however, this specific activity was not attained for the free proteinase until after chromatofocusing and gel filtration, and these two subsequent steps were consequently included in the purification scheme. A significant increase in the purity of the cell wall proteinase was not attained upon further chromatography, but it was nevertheless carried out in order to compare this enzyme's chromatographic characteristics with those of the free proteinase.

\section{Chromatofocusing and gel filtration}

The elution profiles obtained upon chromatofocusing the free and cell wall proteinases were nearly identical (Fig. 4). In both cases there were two activity peaks with coinciding $A_{280}$ peaks which eluted with apparent isoelectric points of $4 \cdot 3$ and $4 \cdot 1$. The two elution profiles differed in that there was relatively more of the 4.3 isoelectric point proteinase component in the free than in the cell-wall-derived preparation. There was also an $A_{280}$ peak eluting with an isoelectric point of $4 \cdot 2$ (Fig. 4), and this peak was due to an inactive degradation product of the proteinases (see results below). The isoelectric points are similar to the values of $4 \cdot 40-4.55$ obtained upon 
Table 1. Purification of the free extracellular and cell wall proteinases

\begin{tabular}{|c|c|c|c|c|c|c|c|c|c|c|c|c|}
\hline \multirow[b]{2}{*}{ Fraction } & \multicolumn{6}{|c|}{ Free extracellular proteinase } & \multicolumn{6}{|c|}{ Cell wall proteinase } \\
\hline & $\begin{array}{l}\text { Vol. } \\
(\mathrm{ml})\end{array}$ & $\begin{array}{l}\text { Total } \\
A_{280^{*}}\end{array}$ & $\begin{array}{c}\text { Enzyme } \\
\text { units }\end{array}$ & $\begin{array}{l}\text { Sp. } \\
\text { act. } \dagger\end{array}$ & $\begin{array}{l}\text { Purif. } \\
\text { (-fold }) \ddagger\end{array}$ & $\begin{array}{l}\text { Yield } \\
(\%)\end{array}$ & $\begin{array}{l}\text { Vol. } \\
(\mathrm{ml})\end{array}$ & $\begin{array}{l}\text { Total } \\
\boldsymbol{A}_{280^{*}}\end{array}$ & $\begin{array}{c}\text { Enzyme } \\
\text { units }\end{array}$ & $\begin{array}{l}\text { Sp. } \\
\text { act. } \dagger\end{array}$ & $\begin{array}{l}\text { Purif. } \\
\text { (-fold) } \ddagger\end{array}$ & $\begin{array}{l}\text { Yield } \\
(\%)\end{array}$ \\
\hline $\begin{array}{l}\text { Culture medium } \\
\text { Extract derived }\end{array}$ & 3000 & 87000 & 46000 & 0.5 & 1 & 100 & - & - & - & - & - & - \\
\hline $\begin{array}{l}\text { from cell wall } \\
\left(\mathrm{NH}_{4}\right)_{2} \mathrm{SO}_{4}\end{array}$ & - & - & - & - & - & - & 120 & 420 & 30000 & 70 & 1 & 100 \\
\hline $\begin{array}{l}\text { precipitation } \\
\text { Binding to }\end{array}$ & 150 & 650 & 82000 & 125 & 250 & 175 & - & - & - & - & - & - \\
\hline $\begin{array}{l}\text { Phenyl Sepharose } \\
\text { Anion exchange }\end{array}$ & 50 & 60 & 134000 & 2200 & 4400 & 290 & 30 & 45 & 25000 & 550 & 8 & 80 \\
\hline $\begin{array}{l}\text { chromatography } \\
\text { Hydrophobic } \\
\text { interaction }\end{array}$ & 8 & 6 & 135000 & 22500 & 45000 & 290 & 4 & $0 \cdot 75$ & 27000 & 36000 & 500 & 88 \\
\hline chromatography & 10 & 3 & 117000 & 39000 & 78000 & 250 & 8 & $0 \cdot 3$ & 13000 & 43000 & 610 & 43 \\
\hline Chromatofocusing & 5 & 1.5 & 42000 & 28000 & 56000 & 90 & 4 & $0 \cdot 2$ & 8000 & 40000 & 550 & 26 \\
\hline Gel filtration & 30 & 0.35 & 13000 & 37000 & 74000 & 28 & 30 & 0.04 & 1400 & 35000 & 500 & 5 \\
\hline
\end{tabular}

* Total $A_{280}$ is the absorbance at $280 \mathrm{~nm}$ multiplied by the volume.

$\dagger$ Specific activity is the enzyme activity (in EU) divided by the absorbance at $280 \mathrm{~nm}$.

$\ddagger$ Purification (-fold) is the increase in specific activity.

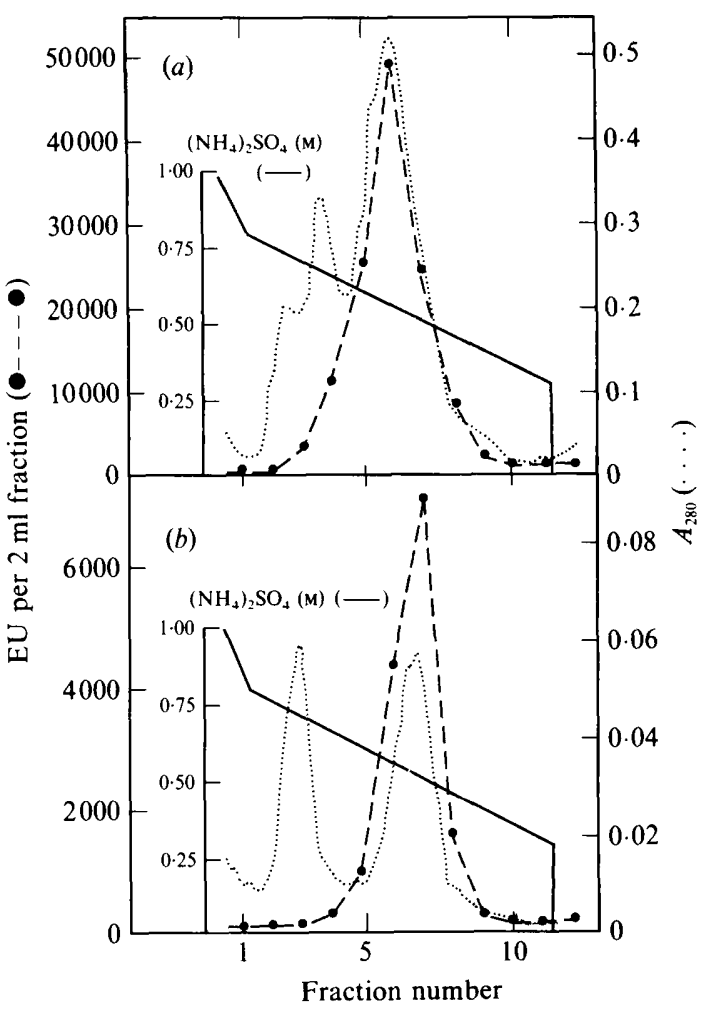

Fig. 3. Hydrophobic interaction chromatography on a Phenyl Superose column of the $(a)$ free and $(b)$ cell wall proteinases which eluted from the Mono $Q$ column. The proteinases were from a 3 litre culture. No activity was detected in the flow-through fraction.

isoelectric focusing the cell wall proteinase from other strains (Exterkate \& de Veer, 1987; Hugenholtz et al., 1987).
Upon gel filtration of the free $4 \cdot 3$ isoelectric point proteinase component, a major activity and $A_{280}$ peak eluted at an $M_{\mathrm{r}}$ of about 300000 , with a marked shoulder at an $M_{\mathrm{r}}$ of 175000 (Fig. $5 a$ ). The free 4.1 isoelectric point component eluted with an $M_{\mathrm{r}}$ of about 125000 (Fig. $5 b$ ). Similar results were obtained with the cell wall proteinase (data not shown). The material absorbing at $280 \mathrm{~nm}$ which eluted after the proteinase activity peaks (Fig. 5) was due to auto-degradation products, since the $A_{280}$ in this part of the elution profile was minimal when the proteinase was inactivated by exposure to $\mathrm{HCl}(\mathrm{pH} \mathrm{2.5)}$ ) prior to gel filtration (data not shown).

\section{Gel electrophoretic analysis of the proteinase}

The proteinase fractions obtained after gel filtration were concentrated by chromatography on a Mono $Q$ anion exchange column at $\mathrm{pH} 7.5$ and subsequently analysed by SDS-PAGE. Two major proteins (termed prol50 and prol15) with proteinase activity were identified in the free proteinase preparation (Fig. 6, lanes 2 and 3 ; similar data were obtained for the cell wall proteinase, but are not presented). Prol 50 eluted with an $M_{\mathrm{r}}$ of 300000 upon gel filtration (Fig. $5 a$ ); it was released from the Mono Q column at about $0.22 \mathrm{M}-\mathrm{NaCl}$ (data not shown), and its $M_{\mathrm{r}}$ as judged by SDS-PAGE was 150000 (Fig. 6, lane 2). It thus appears to be a dimer under nondenaturing conditions. The $M_{\mathrm{r}}$ of prol 50 as determined by SDS-PAGE is similar to the values of $130000-150000$ previously reported for the mature cell wall proteinase of 


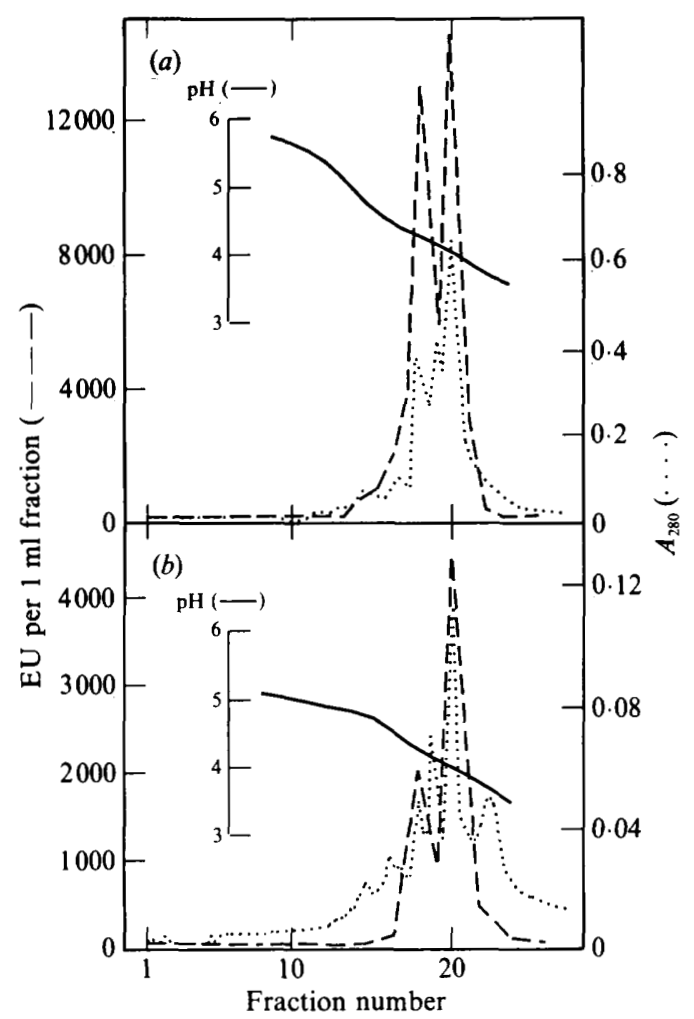

Fig. 4. Chromatofocusing on a Mono P column of the (a) free and (b) cell wall proteinases which eluted from the Phenyl Superose column. The proteinases were from a 3 litre culture. No activity was detected in the flow-through fraction.

other strains (Bockelmann et al., 1989; Exterkate \& de Veer, 1987; Geis et al., 1985; Hugenholtz et al., 1987). Prol15 eluted with an $M_{\mathrm{r}}$ of about 125000 upon gel filtration (Fig. $5 b$ ); it was released from the Mono $Q$ column at about $0 \cdot 25 \mathrm{M}-\mathrm{NaCl}$ (data not shown), and its $M_{\mathrm{r}}$ as judged by SDS-PAGE was 115000 (Fig. 6, lane 3). Thus, prolls is a monomer under non-denaturing conditions. Prol 15 is a degradation product of pro150, as judged by the cleavage products obtained upon incubating prol 50 at $37^{\circ} \mathrm{C}$ (see results below).

Upon concentrating prol15 on the Mono $\mathrm{Q}$ column prior to SDS-PAGE, a major $A_{280}$ peak also eluted at $0.23 \mathrm{M}-\mathrm{NaCl}$. This peak contained a protein of $M_{\mathrm{r}} 90000$ (termed p90; Fig. 6, lane 4; similar data were obtained for the cell wall proteinase, but are not presented). As judged by the cleavage products obtained upon incubating pro 115 at $37^{\circ} \mathrm{C}$, and the fact that prol 15 and $\mathrm{p} 90 \mathrm{had}$ the same $\mathrm{N}$-terminus (see results below), p90 is a degradation product of prol15. The active site of the proteinase is in the $\mathrm{N}$-terminal half of the enzyme (Kok et al., 1988b; Vos et al., 1989a), and p90 should consequently contain the active site. Despite this,

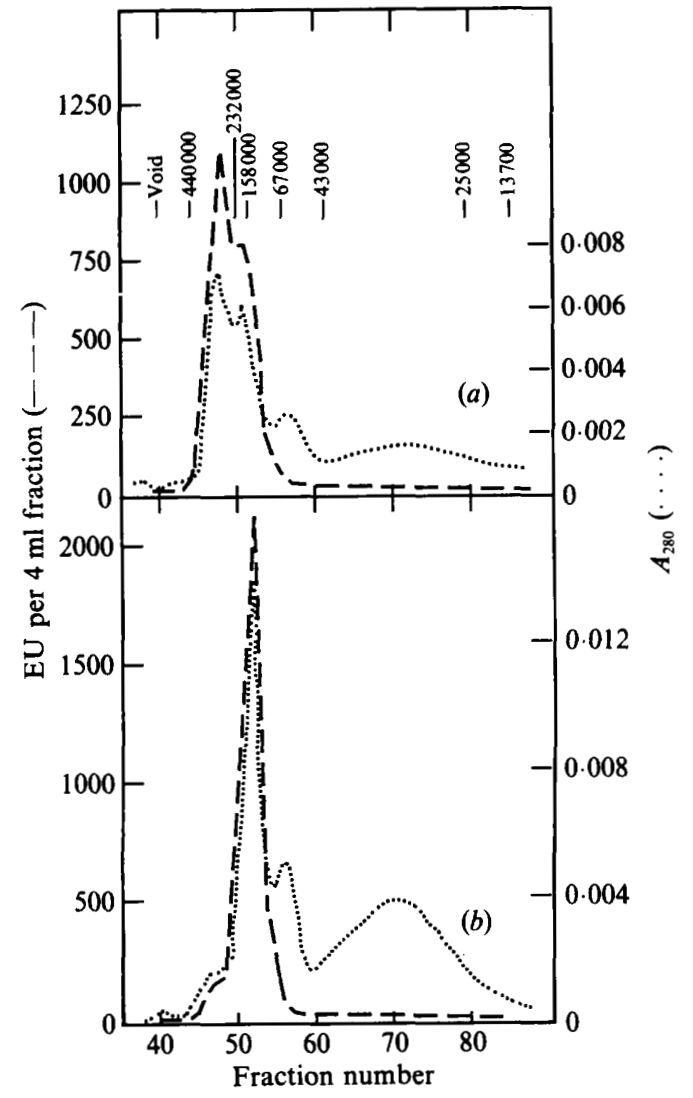

Fig. 5. Gel filtration on a Sephacryl S-200 column of the free proteinase which eluted with an isoelectric point of $(a) 4 \cdot 3$ and $(b) 4 \cdot 1$ upon chromatofocusing. The proteinase was from a 3 litre culture.

p90 had little if any proteinase activity, since no activity peak coincided with the $A_{280}$ peak of p90 when it was chromatographed on the Mono $\mathrm{Q}$ column (data not shown).

Analysis by SDS-PAGE of fractions obtained upon chromatofocusing (Fig. 4) revealed that the peaks eluting with isoelectric points of 4.3 and 4.1 were due to prols0 and prol15, respectively, whereas the $A_{280}$ peak eluting with an isoelectric point of 4.2 was due to p90 (data not shown). Similar analysis of fractions obtained upon anion exchange chromatography (Fig. 2) revealed that prol50 was in fractions 9-12 and prol15 in fractions 13-15 (data not shown). Upon hydrophobic interaction chromatography (Fig. 3), prol 50 was similarly shown to elute slightly ahead of prol15 (data not shown).

The relative amount of prol 50 as compared to prol 15 was higher in the free than in the cell-wall-derived preparation. The two proteinase preparations were otherwise similar, indicating that the free and cell wall proteinases were related. The differences observed in their chromatographic behaviour may be explained by the relatively greater amount of prol50 in the free 


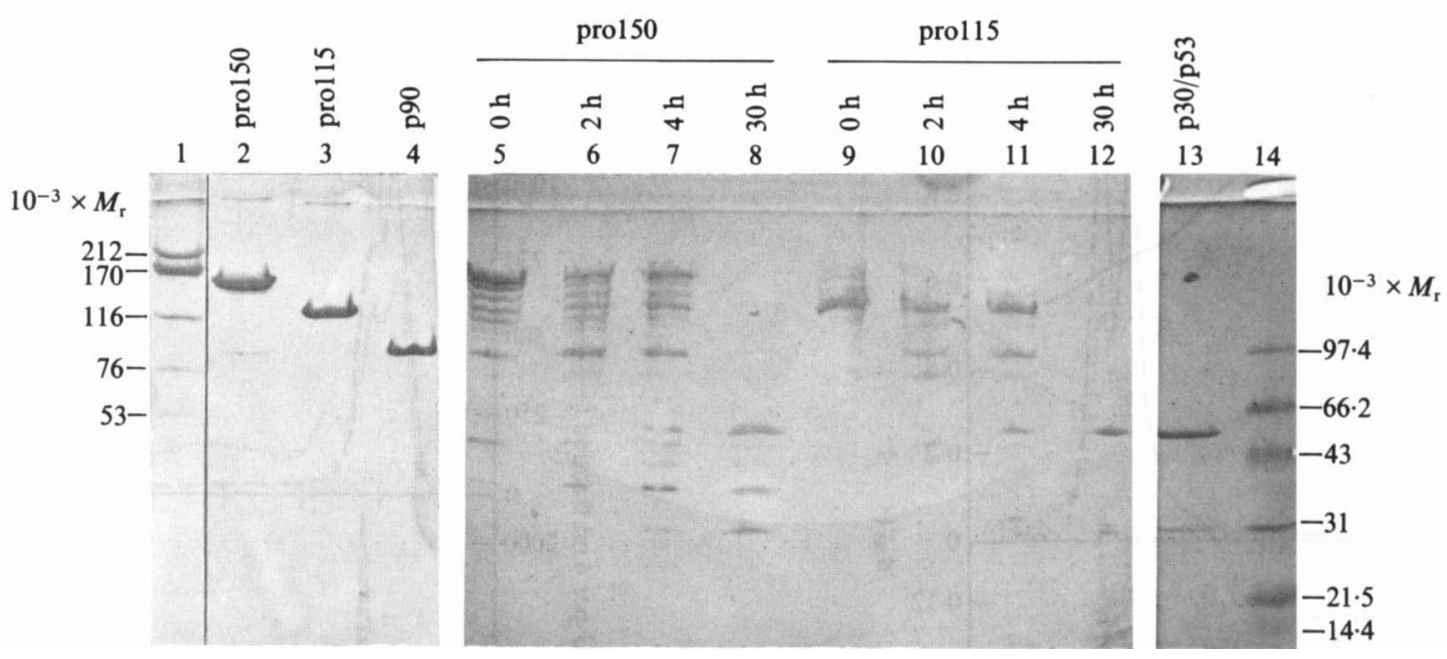

Fig. 6. Analysis by SDS-PAGE of the free proteinase and its autoproteolytic cleavage products. Lanes 1 and 14 show the high- and low$M_{\mathrm{r}}$ standards, respectively. Lanes 2, 3, 4 and 13 show the purified prol 50, prol15, p90, and p 53 and p30, respectively. The preparations analysed in lanes 3, 4 and 13 were used for $\mathrm{N}$-terminal sequencing. Lanes 5-8 and 9-12 show the autoproteolytic cleavage products obtained upon incubating, respectively, prol50 and prol 15 at $37^{\circ} \mathrm{C}$ for the times indicated. The final chromatofocusing and gel filtration steps of the purification procedure were not included when isolating pro 150 and prol 15 for the degradation experiment shown in lanes 5-12. Lanes 1-4 are from the same gel, and similarly for lanes 5-12 and 13-14.

preparation combined with the fact that prol50 is less hydrophobic, has a slightly higher isoelectric point, and binds less tightly to anion exchangers than prol15.

\section{Autoproteolytic cleavage and $N$-terminal amino acid sequencing}

To identify autodegradation products, pro150 and prol15 were incubated at $37^{\circ} \mathrm{C}$ and subsequently analysed by SDS-PAGE (Fig. 6, lanes 5-12). Incubating prol 50 for 2 and $4 \mathrm{~h}$ resulted in a relative increase in prol15 and p90 as well as proteins of $M_{\mathrm{r}}$ less than 60000 (Fig. 6, lanes 5-7). Similarly, incubating prol 15 for 2 and $4 \mathrm{~h}$ resulted in a relative increase in p90 (Fig. 6, lanes 9 11). Incubating prol 50 for $30 \mathrm{~h}$ resulted in the degradation of prol50, pro115 and p90, and the accumulation of three distinct proteins of $M_{\mathrm{r}}$ about 53000,37000 and 30000 - termed, respectively, p53, p37 and p30 (Fig. 6, lane 8). Only p 53 and p 30 were obtained upon incubating prol 15 for $30 \mathrm{~h}$ (Fig. 6, lane 12), indicating that $\mathrm{p} 37$ was produced upon cleavage of prol50 to prol15. Since prol 50 was a dimer and prol 15 a monomer, dimerization of prol 50 depended on a sequence in p37.

An attempt was made to purify these degradation products from each other. However, p53 and p30 coeluted upon both anion exchange chromatography and chromatofocusing, whereas $\mathrm{p} 37$ was not recovered. The fraction obtained after chromatofocusing contained on a molar basis roughly two times more of p53 than p30, as judged by the relative intensity of the two bands detected upon SDS-PAGE analysis of the chromatofocusing fraction (Fig. 6, lane 13).

The $\mathrm{N}$-terminal sequence was determined for prol15, p90, p53 and p30 in order to: (i) definitely show that the free and cell wall proteinases were related and that the degradation products in fact derived from the proteinase, (ii) identify autoproteolytic cleavage sites and thereby gain insight into the amino acid specificity of the proteinase, and (iii) obtain information as to the parts of the mature proteinase from which the cleavage products stemmed. Two sequences were obtained for the fraction containing both p53 and p30 (Fig. 6, lane 13). The first nine amino acids of the two sequences were Asp-AlaLys-Ala-Asn-Ser-Met-Ala-Asn and Gln-Asp-Asn-GluMet-Val-Gly-Thr-Pro, respectively. There was $1 \cdot 5-2 \cdot 0$ times more of the former sequence than the latter, indicating that the former sequence was that of $\mathrm{p} 53$ and the latter that of $\mathrm{p} 30$. Moreover, this is consistent with the determined $M_{\mathrm{r}}$ of 30000 for p30 (see Fig. 7). Both prol15 and $\mathrm{p} 90$ had the same $\mathrm{N}$-terminal sequence as p53.

The nucleotide sequence was recently determined for the gene encoding the cell wall proteinase of $L$. lactis subsp. cremoris strains Wg2 and SK 11 (Kok et al., 1988b; Vos et al., 1989a). The proteinase gene from these two strains codes for a protein with, respectively, 1902 and 1962 amino acids, and there is an overall homology between the genes of $98 \%$ ( 44 amino acid substitutions). The cell wall proteinase from strain SK 11 is synthesized as a pre-pro-protein (Vos et al., 1989a,b). The pre-prosequence is removed by cleavage between $\mathrm{Thr}-187$ and 


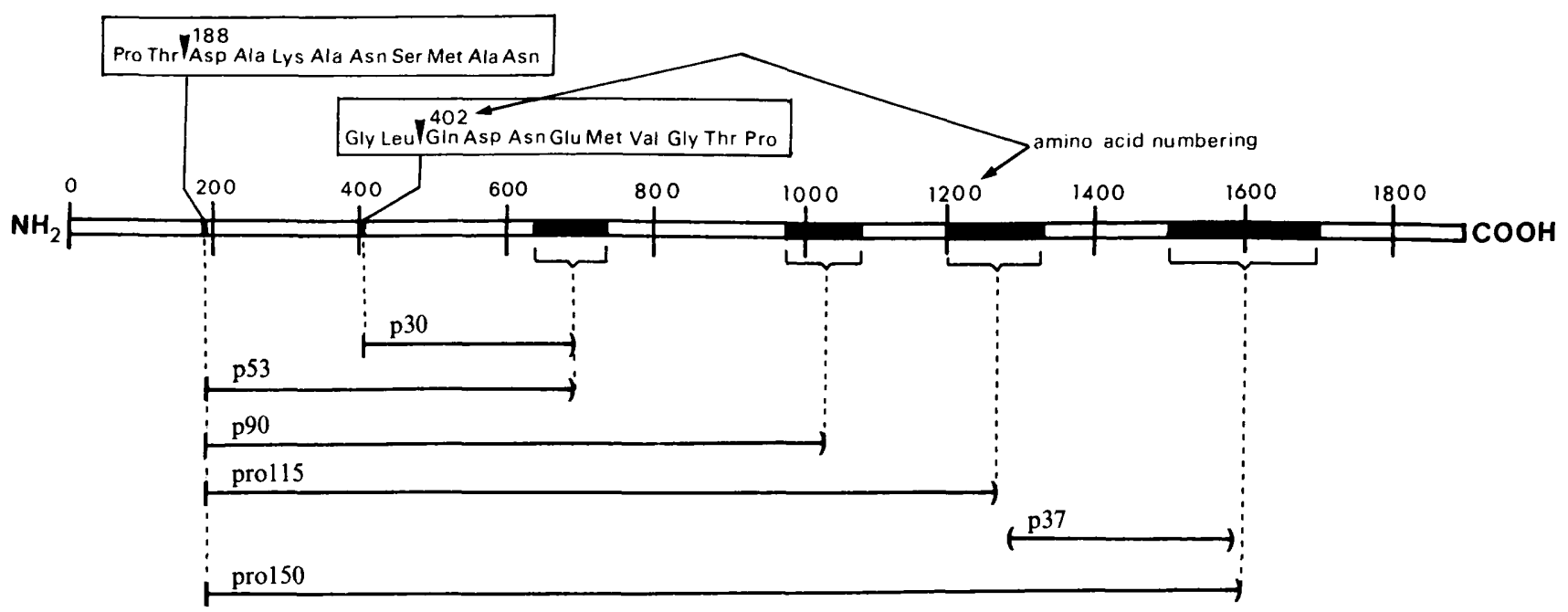

Fig. 7. A model illustrating the autoproteolytic cleavage sites and products, and the parts of the mature proteinase from which the cleavage products derived. Although not determined, it is proposed that the $\mathrm{N}$-terminal sequence of prol 50 also starts with amino acid residue number 188 , as is the case for the mature cell-wall-derived proteinase from $L$. lactis subsp. cremoris strain SK11 (Vos et al., $1989 a, b$ ). The amino acid numbers 186, 187, 400 and 401 (Pro, Thr, Gly and Leu), the total length of 1900-2000 amino acids for the initial translation product, and the amino acid numbering were all derived from the nucleotide sequence of the proteinase gene of strains Wg2 (Kok et al., 1988b) and SK11 (Vos et al., 1989a).

Asp-188, generating the mature cell wall proteinase with Asp-188 as the $\mathrm{N}$-terminal amino acid. Judging from the $\mathrm{N}$-terminal sequencing, the prol 50 degradation products prol15, p90 and p53 all contained Asp-188 at the Nterminus, whereas p30 contained Gln-402. These sequences are identical to the corresponding sequences of the cell wall proteinases from strains $\mathrm{Wg} 2$ and SK11 (Kok et al., 1988b, Vos et al., 1989a). It thus appears that the extracellular proteinase activity produced by $L$. lactis subsp. cremoris is due to basically one type of proteinase which may be present both in a cell-wall-associated and a free form, although small structural differences may exist in the proteinase obtained from different strains (Kok et al., 1988b, Kok \& Venema, 1988; Vos et al., 1989a).

A summary of the results on the autoproteolytic cleavage and N-terminal sequencing is shown in Fig. 7. The figure also illustrates from what parts of the mature proteinase the cleavage products derived, as judged from their $\mathrm{N}$-terminal sequence and their $M_{\mathrm{r}}$ values. The active site of the proteinase involves Asp-217, His-281 and Ser-620 (Kok et al., 1988b; Vos et al., 1989b), and this part is most resistant to autoproteolytic cleavage as judged by the degradation products obtained (Fig. 7). It is interesting to note that the cleavage site between amino acid numbers 401 and 402 was adjacent to Gln (Fig. 7), in view of the fact that of seven identified sites in casein at which the cell wall proteinase cleaves, five were adjacent to Gln (Visser et al., 1988). Cleavage at the autoproteolytic cleavage site between amino acid residues 401 and 402, and at a cleavage site between residues 640 and 740, and between residues 975 and 1075, inactivates the proteinase. Altering the amino acid sequence in these regions may be a means by which proteinases less prone to autoproteolytic inactivation may be generated.

We are grateful to Dr Ingolf Nes for his continuing interest and helpful discussions.

This work was supported by the Agricultural Research Council of Norway.

\section{References}

Bockelmann, W., Monnet, V., Geis, A., Teuber, M. \& Gripon, J. C. (1989). Comparison of cell wall proteinases from Lactococcus lactis subsp. cremoris AC1 and Lactococcus lactis subsp. lactis NCDO 763. I. Purification and action of the enzyme on caseins. Applied Microbiology and Biotechnology 31, 278-282.

EXTERKATE, F. A. \& DE Veer, G. (1987). Complexity of the native cell wall proteinase of Lactococcus lactis subsp. cremoris HP and purification of the enzyme. Systematic and Applied Microbiology 9, 183-191.

Fox, P. F. (1989). Proteolysis during cheese manufacture and ripening. Journal of Dairy Science 72, 1379-1400.

Geis, A., BockelmanN, W. \& Teuber, M. (1985). Simultaneous extraction and purification of a cell wall-associated peptidase and $\beta$ casein specific protease from Streptococcus cremoris AC1. Applied Microbiology and Biotechnology 23, 79-84.

HaAndrikman, A. J., KoK, J., LaAn, H., Soemitro, S., Ledeboer, A. M., Konings, W. N. \& Venema, G. (1989). Identification of a gene required for maturation of an extracellular lactococcal serine proteinase. Journal of Bacteriology 171, 2789-2794.

Hatcher, V. B., Lazarus, G., Levine, N., Burk, P. \& Yost, F. (1977). Characterization of a chemotactic and cytotoxic proteinase from human skin. Biochimica et Biophysica Acta 483, 160-171.

Hugenholtz, J., Exterkate, F. \& Konings, W. N. (1984). The proteolytic systems of Streptococcus cremoris: an immunological analysis. Applied and Environmental Microbiology 48, 1105-1110. 
Hugenholtz, J., van Sinderen, D., KoK, J. \& Konings, W. N. (1987). Cell wall-associated protease of Streptococcus cremoris Wg2. Applied and Environmental Microbiology 53, 853-859.

KoK, J. \& Venema, G. (1988). Genetics of proteinases of lactic acid bacteria. Biochemie 70, 475-488.

KoK, J., Hill, D., HaAndrikman, A. J., de Reuver, M. J. B., LaAn, H. \& Venema, G. (1988a). Deletion analysis of the proteinase gene of Streptococcus cremoris Wg2. Applied and Envornmental Microbiology 54, 239-244.

Kok, J., Leenhouts, K. J., HaAndrikman, A. J., Ledeboer, A. M. \& VENEMA, G. $(1988 b)$. Nucleotide sequence of the cell wall proteinase gene of Streptococcus cremoris Wg2. Applied and Environmental Microbiology 54, 231-238.

LAAN, H. \& Konings, W. N. (1989). Mechanism of proteinase release from Lactococcus lactis subsp. cremoris $\mathrm{Wg}$ 2. Applied and Environmental Microbiology 55, 3101-3106.

LaAn, H., Smid, E. J., de Leij, L., Schwander, E. \& Konings, W. N. (1988). Monoclonal antibodies to the cell-wall-associated proteinase of Lactococcus lactis subsp. cremoris $\mathrm{Wg} 2$. Applied and Environmental Microbiology 54, 2250-2256.
Law, B. A. \& Kolstad, J. (1983). Proteolytic systems in lactic acid bacteria. Antonie van Leeuwenhoek 49, 225-245.

Thomas, T. D. \& Mills, O. E. (1981). Proteolytic enzymes of starter bacteria. Netherlands Milk and Dairy Journal 35, 255-273.

Visser, S., Slangen, C. J., Exterkate, F. A. \& de Veer, G. J. (1988). Action of a cell wall proteinase (PI) from Streptococcus cremoris $\mathrm{HP}$ on bovine $\beta$-casein. Applied Microbiology and Biotechnology 29, 61-66.

Vos, P., Simons, G., Siezen, R. J. \& DE Vos, W. M. (1989a). Primary structure and organization of the gene for a procaryotic, cell envelope-located serine proteinase. Journal of Biological Chemistry 264, 13579-13585.

Vos. P., van Asseldonk, M., van Jeveren, F., Siezen, R., Simons, G. \& DE VOS, W. M. (1989b). A maturation protein is essential for production of active forms of Lactococcus lactis SK11 serine proteinase located in or secreted from the cell envelope. Journal of Bacteriology 171, 2795-2802. 